\title{
Effect of planting date on postharvest quality of roots of different carrot cultivars grown in the Brazilian semiarid region
}

\author{
Victor Emmanuel de Vasconcelos Gomes ${ }^{1 * \mathbb{D}}$, Núbia Marisa Ferreira ${ }^{1}$, Leilson Costa Grangeiro ${ }^{1}$, \\ Rodolfo Rodrigo de Almeida Lacerda ${ }^{1}$, Antonio Fabrício de Almeida ${ }^{1}$, João Paulo Nunes da Costa ${ }^{1}$
}

10.1590/0034-737X202067050003

\begin{abstract}
In regions with high temperatures, carrot cultivation is difficult because high temperatures tend to reduce the size and pigmentation of the root and, consequently, the yield and quality of the product. However, with the advent of summer cultivars, the cultivation of quality carrots under high temperatures has been viable. The aim of this work was to evaluate the postharvest quality of ten carrot cultivars as a function of different planting dates. The experiments were carried out on the Rafael Fernandes Experimental Farm of the Universidade Federal Rural do Semi-Árido (UFERSA). Four experiments were carried out in May, June, July and August 2017. The experimental design was a randomized block with ten treatments and four replications. The following was evaluated: white halo percentage, soluble solids content, total soluble sugars, total titratable acidity, soluble solids/titratable acidity ratio and beta-carotene content. The interaction between the carrot cultivars and planting date had a significant influence on the postharvest quality of carrot roots. The hybrid cultivars had an overall better post-harvest quality. The carrots sown in July had better quality traits; however, they were more affected by the "white halo" disorder.
\end{abstract}

Keywords: Daucus carota L.; adaptability; consumer preference; limiting environment.

\section{INTRODUCTION}

Modern agriculture has increasingly sought to maximize available resources, aimed not only at increasing productivity, as in the past, but also at seeking higher quality food. Nowadays, due to the greater degree of knowledge about the quality of products, consumers are giving preference to fresh produce that is smaller in size and has greater nutritional value (Hoppu et al., 2020).

The chemical composition of carrot roots is variable and influenced by genetic factors and cultivation conditions, such as crop system, soil type and physical properties, planting time, rainfall, and temperature during the growing season (Seljåsen et al., 2013), as well as phytosanitary aspects, fertilization, and planting density.

Among the climatic and management factors that affect carrot quality, precipitation and irrigation are very important (Soltoft, 2010). Stress from high or low water availability in the soil can induce the production of undesirable compounds (Reid \& Gillespie, 2017). Other important factors are temperature and light conditions. Warm and humid climates seem to affect quality by inducing a turpentine-flavored, less sweet-tasting carrot compared to carrots grown in cooler and drier climates. It is known that low cultivation temperatures $\left(9-21^{\circ} \mathrm{C}\right)$ affect the sensory aspect by increasing the sweet taste $(+35 \%)$ and content of fructose $(+49 \%)$ and glucose $(+28 \%)$ and reducing the bitter taste (" $30 \%)$ and content of sucrose (“33\%) and â-carotene (“40\%) (Seljåsen et al., 2013).

Therefore, understanding the environmental conditions in different regions and climates where a crop is grown is crucial when choosing a cultivar.

In order to overcome the limitations imposed by high temperatures, Brazilian researchers have developed cultivars that perform well in the temperature range of 18 to $25^{\circ} \mathrm{C}$. The new varieties, in addition to good climate adaptability, have resistance to diseases caused by fungi

\footnotetext{
Submitted on March 16 $6^{\text {th }}, 2020$ and accepted on July 21st, 2020.

${ }^{1}$ Universidade Federal Rural do Semiárido, Programa de Pós Graduação em Agronomia/Fitotecnia, Mossoró, Rio Grande do Norte, Brazil.v.e.de.v.gomes@gmail.com; nubiamarisa1@hotmail.com; leilson@ufersa.edu.br; rodolfo-lacerda@hotmail.com; fabricioalmeida@ufersa.edu.br; jppoty@hotmail.com

*Corresponding Author: v.e.de.v.gomes@gmail.com
} 
and nematodes. This makes it possible to cultivate carrots in regions and states where the temperatures are higher, such as Bahia and Goiás (Silva et al., 2011).

The use of summer cultivars and seeds from primary umbels has been the main strategy to enable carrot cultivation in regions where this vegetable was not cultivated in the past (Resende et al., 2016).

Although the summer cultivar Brasilia is still one of the most widely used in warm regions during summer, in recent years the planted area using imported hybrid cultivars has also increased and research using these new materials, mainly in high temperature conditions, is still incipient. Among the advantages of hybrid cultivars over open-pollinated cultivars are the higher degree of hybrid heterosis and vigor, as well as greater uniformity of internal root color and low presence of white halo.

However, in some states, even with the advent of summer and hybrid cultivars, carrot production is insufficient to meet the domestic demand. In the state of Rio Grande do Norte, where virtually all commercialized carrots come from Bahia, the price of this product in local markets is usually well above the average of the Brazilian market (Bezerra Neto et al., 2014).

Additional research is needed due to the difficulties of carrot production in warm and lower elevation regions, starting with the selection of cultivars with genetic potential for quality root production under high temperatures.

Thus, it is assumed that the planting date influences the postharvest quality of carrot roots due to climatic and environmental variations, such as precipitation, temperature, and cloudiness.

In order to provide more information about the behavior of new carrot cultivars under limiting environmental conditions, the objective of this study was to evaluate the effects of planting dateson the root quality of ten carrot cultivars under semiarid conditions, in Mossoró, Rio Grande do Norte.

\section{MATERIAL AND METHODS}

\section{Location and characterization of the area}

The experiments were carried out on the Rafael Fernandes Experimental Farm, 20 km from Mossoró, RN (Latitude 5 03 '37'S; Longitude 37 $23^{\circ}$ '50" W; average elevation 72m), in a sandy loam, Argissolic Red Latosol (Embrapa, 2016). Four experiments were conducted, with planting in May (Season 1), June (Season 2), July (Season 3) and August (Season 4) 2017.

The climate of the region according to the Köppen classification is BSwh', dry and very hot, with two seasons: a dry season, which is usually from June to January; and a rainy season, between February and May (Carmo Filho et al., 1991). Table 1 shows the monthly averages for temperature, relative humidity, precipitation and solar radiation during the experiments.

For the chemical characterization of the soil, soil samples were collected from 0 to $20 \mathrm{~cm}$ deep. Results are presented in Table 2. Since the experiments were carried out in adjacent areas, only a composite sample was taken from the experimental area for analysis.

\section{Treatments and experimental design}

The experimental design was a completely randomized block with 10 treatments and four replications. The treatments consisted of the Brasilia (TopSeed®), BRS Planalto (ISLA $\left.{ }^{\circledR}\right)$, Supreme (ISLA $\left.®\right)$, Nativa (Sakata ${ }^{\circledR}$ ), Kuronan (ISLA $®)$, Mariana (Feltrin $®)$, Melinda (Feltrin $\left.{ }^{\circledR}\right)$, Amanda, (Agristar $\left.{ }^{\circledR}\right)$, Francine (Agristar $\AA$ ) and Erica (Agristar®) cultivars, cultivated in May, June, July and August. Each experimental plot consisted of a $3.0 \times 1.0 \mathrm{~m}$ seedbed with six rows of plants spaced $0.15 \times 0.06 \mathrm{~cm}$ apart. The four central rows were considered the harvestable area and one plant at each end was neglected.

\section{Implementing and conducting the experiment}

The tillage consisted of plowing, harrowing and raising the beds to a height of approximately $0.20 \mathrm{~m}$. Planting fertilization was performed based on a soil analysis and recommendations by carrot producers in the region, with adaptations made according to the need of the crop. For each planting, we applied $120 \mathrm{~kg} \cdot \mathrm{ha}^{-1}$ of N, $460 \mathrm{~kg} \cdot \mathrm{ha}^{-1}$ of $\mathrm{P}_{2} \mathrm{O}_{5}$ and $110 \mathrm{~kg}$.ha ${ }^{-1}$ of $\mathrm{S}$ using mono ammonium phosphate.

Fertilization was performed three times a week, via fertigation, from 15 to 90 days after germination, using $98.4 \mathrm{~kg} \cdot \mathrm{ha}^{-1} \mathrm{~N}, 300 \mathrm{~kg} \cdot \mathrm{ha}^{-1} \mathrm{P}_{2} \mathrm{O}_{5}, 170 \mathrm{~kg} \cdot \mathrm{ha}^{-1} \mathrm{~K}_{2} \mathrm{O}, 7.1 \mathrm{~kg} \cdot \mathrm{ha}^{-1}$ Mg, 1 kg.ha- ${ }^{-1} \mathrm{Ca}, 13.7 \mathrm{~kg} \cdot \mathrm{ha}^{-1} \mathrm{~S}$ and $1.7 \mathrm{~kg} \cdot \mathrm{ha}^{-1} \mathrm{~B}$ for each experiment. Micronutrients were supplied at a dosage of $2.1 \% \mathrm{~B}, 0.36 \% \mathrm{Cu}, 2.66 \% \mathrm{Fe}, 2.48 \% \mathrm{Mn}, 0.036 \% \mathrm{Mo}$ and $3.38 \% \mathrm{Zn}$. The micronutrient source also had a proportion of $1.6 \% \mathrm{~K}_{2} \mathrm{O}, 1.28 \% \mathrm{~S}$ and $0.86 \% \mathrm{Mg}$. A phytosanitary product was applied to control gall nematodes.

Sowing was performed manually in the transverse direction of the bed in holes approximately $2.0 \mathrm{~cm}$ deep, placing 3 to 4 seeds per hole. Thinning was performed 25 days after sowing (DAS), leaving one plant per hole.

The irrigation system used in the first 15 days after sowing was a micro sprinkler. During the remainder of the crop cycle, drip irrigation was used. Dripping was performed with three hoses per seedbed, spaced $0.15 \mathrm{~m}$ apart and with drippers every $0.20 \mathrm{~m}$. Irrigation was performed daily, with the irrigation depth based on crop evapotranspiration (Allen et al., 2006).

Harvesting was performed when the older leaves yellowed and dried and the younger leaves bent down, which occurred, on average, 120 DAS. 


\section{Characteristics evaluated}

For the postharvest quality analysis, 10 commercial roots from the experimental plot area were sampled.

- Soluble solids ( $\left.{ }^{\circ} \mathrm{Brix}\right)$ : The roots were processed in a Philips Walita ${ }^{\circledR}$ Juicer Centrifuge to extract the juice. Then, the juice was filtered with filter paper and read using a digital refractometer with automatic temperature correction.

- Total soluble sugars (\%): This was determined in the juice, using the method of Antrona (Southgate, 1991) and $1 \mathrm{~mL}$ of juice diluted in distilled water in a $250 \mathrm{~mL}$ volumetric flask. An aliquot of $1 \mathrm{~mL}$ was transferred to test tubes and then $2 \mathrm{~mL}$ of anthrone was added and homogenized. Subsequently, the absorbance was determined with a spectrophotometer at a wavelength of $620 \mathrm{~nm}$.

- Total titratable acidity ( $\%$ malic acid): This was determined using the titrometric method. $5 \mathrm{~g}$ of root sample was weighed in a $125 \mathrm{~mL}$ Erlenmeyer flask, completed to $50 \mathrm{~mL}$ with distilled water, and then three to five drops of $1 \%$ phenolphthalein were added and titrated with a $0.1 \mathrm{~N}$ $\mathrm{NaOH}$ solution (Instituto Adolfo Lutz, 2008).

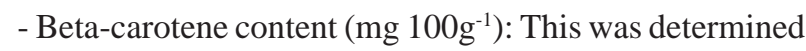
according to a method adapted from Nagata \& Yamashita (1992). After crushing five carrots in a processor, a $0.5 \mathrm{~g}$ sample was taken and $5 \mathrm{~mL}$ of an acetone-hexane mixture (4:6) was added for the extraction. Then, the samples were left to rest for 30 minutes. The readings were made with a spectrophotometer, at wavelengths of 453, 505, 645 and $663 \mathrm{~nm}$, to quantify the levels of $\beta$-carotene according to the equation below: $\beta$-carotene $\left(\mathrm{mg}^{100 \mathrm{~g}^{-1}}\right)=0.216 * \mathrm{~A} 663-1.22 * \mathrm{~A} 645-$ $0.304 * \mathrm{~A} 505+0.452 * \mathrm{~A} 453$

In which A663, A645, A505 and A453 stand for the absorbance of the sample at each of these wavelengths.

- Percentage of white halo in the roots (\%): A sample of ten marketable plants was taken from the useful area of the plot. These plants were cut in half and the presence or absence of the physiological disturbance "white halo" was verified.

\section{Statistical Analysis}

A variance analysis of the evaluated characteristics was performed separately for each experiment. Then, based on the recommendation by Pimentel-Gomes (2009), the experiments were jointly analyzed for the characteristics that passed the homogeneity test. The characteristics that did not present homogeneity were corrected according to the methodology recommended by Pimentel-Gomes (2009). The statistical analyses were performed using the software SISVAR v 5.3 (Ferreira, 2003). To compare the means, the Scott-Knott test at a 5\% probability level was used.

\section{RESULTS AND DISCUSSION}

According to the joint variance analysis, there was an interaction between the cultivar and planting time factors for all of the post-harvest quality related characteristics, except for beta-carotene content (Table 3).

Regarding the white halo percentage, there was a significant difference between cultivars for all planting times. In general, the percentage of carrots with white

Table 1: Meteorological data of the study area during the experiment. Mossoró, RN. Ufersa, 2017

\begin{tabular}{|c|c|c|c|c|c|c|c|c|c|}
\hline \multirow{2}{*}{ Year } & \multirow{2}{*}{ Month } & \multicolumn{3}{|c|}{$\mathbf{T}\left({ }^{\circ} \mathbf{C}\right)$} & \multicolumn{3}{|c|}{ RH(\%) } & \multirow{2}{*}{$\mathbf{R}(\mathbf{m m})$} & \multirow{2}{*}{ S.R. $\left(W / \mathbf{m}^{2}\right)$} \\
\hline & & Mean & Max & Min & Mean & Max & Min & & \\
\hline \multirow{8}{*}{2017} & May & 28.0 & 38.6 & 19.4 & 75.6 & 98.0 & 31.9 & 15.4 & 226.4 \\
\hline & June & 27.7 & 36.3 & 20.7 & 70.8 & 97.3 & 31.5 & 14.2 & 211.3 \\
\hline & July & 27.0 & 35.6 & 19.1 & 66.9 & 98.2 & 29.3 & 58.6 & 198.9 \\
\hline & August & 27.5 & 37.9 & 19.4 & 64.9 & 93.5 & 29.0 & 0.2 & 254.7 \\
\hline & September & 28.0 & 38.5 & 19.6 & 60.4 & 90.8 & 24.5 & 2.4 & 263.6 \\
\hline & October & 28.3 & 38.6 & 21.0 & 64.2 & 91.4 & 29.3 & 0.8 & 267.1 \\
\hline & November & 28.0 & 37.2 & 21.0 & 67.8 & 91.5 & 32.9 & 0.6 & 277.7 \\
\hline & December & 28.4 & 37.3 & 21.8 & 69.2 & 93.5 & 36.7 & 1.4 & 250.9 \\
\hline 2018 & January & 28.1 & 37.5 & 20.3 & 71.7 & 96.6 & 30.0 & 64.4 & 236.1 \\
\hline
\end{tabular}

Note: $\mathrm{T}$ = Temperature; $\mathrm{RH}=$ Relative humidity; $\mathrm{R}=$ Rainfall; S.R. = Solar radiation.

Table 2: Chemical characterization of the soil in the experimental areas. Mossoró, RN. Ufersa, 2017

\begin{tabular}{|c|c|c|c|c|c|c|}
\hline $\mathrm{pH}$ & EC & $\mathbf{P}^{1}$ & $\mathbf{K}^{+}$ & $\mathbf{N a}^{+}$ & $\mathrm{Ca}^{2+}$ & $\mathrm{Mg}^{+2}$ \\
\hline (water) & $\mathrm{dS} \mathrm{m}^{-1}$ & \multicolumn{3}{|c|}{$\mathrm{mg} \mathrm{dm}^{-3}$} & \multicolumn{2}{|c|}{$\mathrm{cmol}^{\mathrm{dm}^{-3}}$} \\
\hline 5.10 & 0.03 & 6.70 & 32.20 & 4.80 & 0.80 & 0.50 \\
\hline
\end{tabular}

${ }^{1}$ Melich Extractor 1 
halo increased with each planting date, from $25 \%$ in Season 1 to $76.2 \%$ in Season 4. The cultivars that showed the highest percentages of the disorder were Brasília, Kuronan and Suprema. The hybrid cultivar Nativa had the lowest percentage (Table 4).

Although the open-pollinated cultivars were more susceptible to this disorder, hybrids were also susceptible. The Amanda cultivar did not exhibit the disorder in Season 1. In seasons 2 and 3, almost half of the roots were affected by white halo. In Season 4, nearly all of the roots of the Amanda cultivar showed the physiological disorder. A similar pattern was observed for the Francine cultivar.

This evolution of the physiological disturbance throughout the planting dates is certainly related to changes in climatic conditions that the plants were subjected to throughout the year, especially temperature, relative humidity and solar radiation. Although high temperatures are determinant for the occurrence of this physiological disorder, some cultivars appeared to be more tolerant (i.e., Melinda and Nativa). It was also observed that the Meloidogyne sp. infection tends to aggravate the problem. Therefore, the increased incidence of white halo in seasons 3 and 4 may also be related to a higher incidence of this disease in the study area.

White halo is a physiological disorder that affects the xylem vessels in carrot roots. It begins as a whitish halo around the vascular bundle and progresses to complete discoloration of the vascular bundle (Grangeiro et al. 2012). Carrot roots with this disorder have low market acceptance. Pereira et al. (2015) point out that in the Brazilian market, for consumption in natura, there is a preference for roots with a pronounced orange color and little differentiation between the colors of the xylem and phloem.

Carrot hybrids showed higher levels of soluble solids compared to open-pollinated cultivars, except for the hybrid Nativa, which was not statistically different from open-pollinated cultivars, and the Suprema cultivar, which was the only open-pollinated cultivar with a soluble solids content statistically similar to the one observed for hybrid cultivars during seasons 1, 3 and 4 (Table 5). The means

Table 3: ANOVA table. Mossoró, RN. Ufersa, 2017

\begin{tabular}{lccccccc}
\hline S.V. & F. D. & WHP & S S & TA & SS/TA & TSS & \multicolumn{1}{c}{ BC } \\
\hline Block & 12 & $3.64^{\mathrm{ns}}$ & $0.3802^{\mathrm{ns}}$ & $0.0015^{\mathrm{ns}}$ & $0.3756^{\mathrm{ns}}$ & $1.5956^{\mathrm{ns}}$ & $0.4577^{\mathrm{ns}}$ \\
Cultivar(C) & 9 & $66.89^{* *}$ & $1.9434^{* *}$ & $0.0064^{* *}$ & $1.9914^{* *}$ & $7.2344^{* *}$ & $1.9380^{* *}$ \\
Planting date (S) & 3 & $214.61^{* *}$ & $13.8576^{* *}$ & $0.0475^{* *}$ & $98.5999^{* *}$ & $13.7020^{* *}$ & $4.6020^{* *}$ \\
Cx S & 27 & $9.14^{* *}$ & $0.6119^{* *}$ & $0.0034^{*}$ & $0.8439^{* *}$ & $4.6366^{* *}$ & $0.6460^{\mathrm{ns}}$ \\
Residual & 105 & 2.82 & 0.2216 & 0.0019 & 0.3220 & 1.1969 & 0.5092 \\
\hline C.V. $(\%)$ & & 28.35 & 4.64 & 14.50 & 13.38 & 14.67 & 29.44
\end{tabular}

Note: $\mathrm{WHP}=$ White halo percentage; $\mathrm{SS}=$ Soluble solids content; TA= Titratable acidity; SS/TA= Soluble solids/Titratable acidity ratio; $\mathrm{TSS}=$ Total soluble sugars; $\mathrm{bC}=$ Beta-carotene content.

$*=$ Significant at $5 \%$ level; $* *=$ Significant at $1 \%$ level; ns= not significant.

Table 4: White halo percentage in carrot roots as a function of the planting date. Mossoró, RN. Ufersa, 2017

\begin{tabular}{|c|c|c|c|c|c|}
\hline \multirow{3}{*}{ Cultivars } & \multicolumn{5}{|c|}{ White halo percentage } \\
\hline & \multicolumn{4}{|c|}{ Planting dates } & \multirow[b]{2}{*}{ Mean } \\
\hline & $\begin{array}{c}\text { May } \\
\text { (Season 1) }\end{array}$ & $\begin{array}{c}\text { June } \\
\text { (Season 2) }\end{array}$ & $\begin{array}{c}\text { July } \\
\text { (Season 3) }\end{array}$ & $\begin{array}{c}\text { August } \\
(\text { Season 4) }\end{array}$ & \\
\hline Amanda & $0.0 \mathrm{cC}$ & $47.5 \mathrm{bB}$ & $47.5 \mathrm{cB}$ & $97.5 \mathrm{aA}$ & 48.1 \\
\hline Brasília & $55.0 \mathrm{bB}$ & $95.0 \mathrm{aA}$ & $100.0 \mathrm{bA}$ & $75.0 \mathrm{bA}$ & 81.3 \\
\hline BRS Planalto & $0.0 \mathrm{cB}$ & $62.5 \mathrm{bA}$ & $60.0 \mathrm{cA}$ & $70.0 \mathrm{bA}$ & 48.1 \\
\hline Érica & $0.0 \mathrm{cC}$ & $62.5 \mathrm{bB}$ & $62.5 \mathrm{cB}$ & $100.0 \mathrm{aA}$ & 46.2 \\
\hline Francine & $2.5 \mathrm{cB}$ & $62.5 \mathrm{bA}$ & $45.0 \mathrm{cA}$ & $70.0 \mathrm{bA}$ & 45.0 \\
\hline Kuronan & $87.5 \mathrm{aA}$ & $97.5 \mathrm{aA}$ & $85.0 \mathrm{bA}$ & $100.0 \mathrm{aA}$ & 92.5 \\
\hline Mariana & $37.5 \mathrm{bB}$ & $77.5 \mathrm{aA}$ & $70.0 \mathrm{cA}$ & $95.0 \mathrm{aA}$ & 70.0 \\
\hline Melinda & $10.0 \mathrm{cB}$ & $50.0 \mathrm{bA}$ & $62.5 \mathrm{cA}$ & $52.5 \mathrm{cA}$ & 43.8 \\
\hline Nativa & $0.0 \mathrm{cC}$ & $22.5 \mathrm{cB}$ & $70.0 \mathrm{cA}$ & $37.5 \mathrm{cB}$ & 32.5 \\
\hline Suprema & $57.5 \mathrm{bB}$ & $92.5 \mathrm{aA}$ & $95.0 \mathrm{bA}$ & $82.5 \mathrm{aA}$ & 81.9 \\
\hline Mean & 25.0 & 67.0 & 69.8 & 76.2 & \\
\hline
\end{tabular}

Means followed by the same letter do not differ statistically (uppercase in the row and lowercase in the column) using the Scott-Knott test at $5 \%$ probability.

Rev. Ceres, Viçosa, v. 67, n.5, p. 357-364, sep/oct, 2020 
of total soluble solids obtained in the present study are above the range of 6.5 to $7.5^{\circ}$ Brix, which is recommended for harvest and consumption (Paulus et al., 2012).

Soluble solids content is directly related to the taste and sweetness of plant products. Therefore, the high soluble solids content value is a positive result, since sweetness is a desirable attribute that increases the quality of carrots (Schifferstein et al., 2018).

Planting in July favored higher levels of soluble solids in the roots in all cultivars (Table 5). The high solar irradiance observed during the cycle of the plants sown in July, especially between September and December 2017, may have caused the greatest accumulation of soluble solids. This is because high luminosity favors an increase in soluble solids content in the plants (by reducing the root weight) and a decrease in acidity, resulting in bettertasting carrots (Mattiuz, 2007).

For the Shin Kuroda cultivar, which belongs to the Kuronan group, the average soluble solids content observed by Paulus et al. (2012) was $9.5^{\circ}$ Brix, with the highest averages observed for carrots grown in the winter. In Mossoró, Grangeiro et al. (2012) report an average of $7.62-8.90^{\circ}$ Brix for the Brasília cultivar.

Regarding titratable acidity, the cultivars did not differ statistically from each other for the planting dates of May and August. In June, the cultivars Brasília, Kuronan and Mariana did not differ from each other and were the ones with the greatest acidity (Table 6). In July, in addition to the cultivars mentioned above, the cultivars Amanda and BRS Planalto also formed the group of cultivars with the highest acidity.

The synthesis of organic acids in a plant is directly related to the photosynthetic capacity of the plant (Taiz
\& Zeiger, 2017). Thus, environmental factors such as temperature and solar radiation, associated with planting density, may have influenced the decrease in the acid content in the roots during the planting dates.

In general, the titratable acidity means found here were similar or approximate to those in the literature. Alves at al. (2010) obtained $0.167 \%$ malic acid for the Brasília cultivar. Pereira (2014) reports that the titratable acidity of conventional and organic carrot samples was 0.19 and $0.2 \%$ malic acid, respectively, with no significant differences between the two cultivation systems.

For the ratio of soluble solids/titratable acidity, there was no significant difference between cultivars in Season 1. Seasons 3 and 4 had the highest soluble solids/total titratable acid (SS/TA) ratios. The increase in the SS/TA ratio during the planting dates was observed for practically all cultivars, except Érica, Melinda and Nativa that showed an increase in Season 3 and a decrease in Season 4 (Table 7).

The Francine, Mariana and Nativa cultivars had the highest SS/TA averages and were statistically equal. The other cultivars did not statistically differ from each other and had averages ranging from 62.61 to 70.78 (Table 7).

The increase in the SS/TA ratio in seasons 3 and 4 is related to the increase in the content of soluble solids in those seasons and to the decrease in the titratable acidity observed in the same seasons.

The results obtained in the present study were superior to those obtained by Figueiredo Neto et al. (2010) (30.8 ${ }^{\circ} \mathrm{Brix} / \%$ for Brasília cultivar) and Alves et al. (2010) $\left({ }^{\circ} \mathrm{Brix} / 50.15 \%\right.$ for Brasília carrot). This difference can be attributed to the difference in soil, spacing, management and local average temperature.

Table 5: Soluble solids content ( ${ }^{\circ}$ Brix) in carrot roots as a function of the planting date. Mossoró, RN. Ufersa, 2017

\begin{tabular}{|c|c|c|c|c|c|}
\hline \multirow{3}{*}{ Cultivars } & \multicolumn{5}{|c|}{ Soluble Solids Content $\left({ }^{\circ}\right.$ Brix $)$} \\
\hline & \multicolumn{4}{|c|}{ Planting dates } & \multirow[b]{2}{*}{ Mean } \\
\hline & $\begin{array}{c}\text { May } \\
\text { (Season 1) }\end{array}$ & $\begin{array}{c}\text { June } \\
\text { (Season 2) }\end{array}$ & $\begin{array}{c}\text { July } \\
\text { (Season 3) }\end{array}$ & $\begin{array}{c}\text { August } \\
\text { (Season 4) }\end{array}$ & \\
\hline Amanda & $10.37 \mathrm{aB}$ & $9.87 \mathrm{aB}$ & $11.22 \mathrm{aA}$ & $10.45 \mathrm{aB}$ & 10.48 \\
\hline Brasília & $9.51 \mathrm{bB}$ & $9.61 \mathrm{bB}$ & $10.57 \mathrm{bA}$ & $9.88 \mathrm{aB}$ & 9.90 \\
\hline BRS Planalto & $9.20 \mathrm{bB}$ & $9.01 \mathrm{bB}$ & $11.07 \mathrm{aA}$ & $9.28 \mathrm{bB}$ & 9.64 \\
\hline Érica & $10.27 \mathrm{aA}$ & $10.20 \mathrm{aA}$ & $11.03 \mathrm{aA}$ & $8.60 \mathrm{bB}$ & 10.36 \\
\hline Francine & $10.20 \mathrm{aB}$ & $10.40 \mathrm{aB}$ & $11.08 \mathrm{aA}$ & $10.46 \mathrm{aB}$ & 10.54 \\
\hline Kuronan & $9.56 \mathrm{bB}$ & $9.15 b B$ & $10.26 \mathrm{bA}$ & $9.72 \mathrm{aB}$ & 9.68 \\
\hline Mariana & $10.02 \mathrm{aB}$ & $10.20 \mathrm{aB}$ & $11.42 \mathrm{aA}$ & $10.52 \mathrm{aB}$ & 10.54 \\
\hline Melinda & $9.06 \mathrm{bB}$ & $10.83 \mathrm{aA}$ & $11.13 \mathrm{aA}$ & $10.40 \mathrm{aA}$ & 10.36 \\
\hline Nativa & $9.38 \mathrm{bC}$ & $9.10 \mathrm{bC}$ & $11.12 \mathrm{aA}$ & $10.06 \mathrm{aB}$ & 9.92 \\
\hline Suprema & $10.10 \mathrm{aB}$ & $9.45 \mathrm{bB}$ & $11.20 \mathrm{aA}$ & $9.86 \mathrm{aB}$ & 10.15 \\
\hline
\end{tabular}

Means followed by the same letter do not differ statistically (uppercase in the row and lowercase in the column) using the Scott-Knott test at $5 \%$ probability. 
The total soluble sugar levels ranged from 6.46 to $8.28 \%$. A significant difference was observed between cultivars in seasons 1, 2 and 3 . In seasons 1 and 2, the cultivars that stood out were the hybrids Amanda, Érica, Francine, and Mariana (Table 8).

In general, it was observed that the concentration of total soluble sugars tended to decrease throughout the year. This shows that planting carrots at the hottest times of the year will result in root quality loss. The lowest concentration of sugars in the hottest times of the year is related to the metabolism of the carrot plant. The carrot is a C3 metabolism plant and, therefore, it tends to undergo photorespiration with increased temperature and solar irradiance, and can also suffer photoinhibition due to high solar radiation, which can damage the photosynthetic apparatus and, consequently, have a direct impact on the ability to synthesize carbohydrates (Taiz \& Zeiger, 2017).

The mean sugar contents found here are in accordance with Umuhoza et al. (2014), who reported that in Brasília type cultivars the sugar content varies in the range of 9.9 to $10.27 \%$, values similar to those found in American cultivars.

The means found by Alves et al. (2010), for the Mossoró region, ranged between 5.12 and $6.32 \%$ and are, therefore, lower than the averages identified in this study, even for the most unfavorable planting times for carrot cultivation in the region.

For the levels of beta-carotene, there was a significant effect of the cultivar factors and planting times alone (Table 9). The cultivars Brasília and Kuronan were similar

Table 6: Titratable acidity (malic acid \%) in carrot roots as a function of the planting date. Mossoró, RN. Ufersa, 2017

\begin{tabular}{|c|c|c|c|c|c|}
\hline \multirow{3}{*}{ Cultivars } & \multicolumn{5}{|c|}{ Titratable Acidity (malic acid \%) } \\
\hline & \multicolumn{4}{|c|}{ Planting dates } & \multirow[b]{2}{*}{ Mean } \\
\hline & $\begin{array}{c}\text { May } \\
\text { (Season 1) }\end{array}$ & $\begin{array}{c}\text { June } \\
\text { (Season 2) }\end{array}$ & $\begin{array}{c}\text { July } \\
\text { (Season 3) }\end{array}$ & $\begin{array}{c}\text { August } \\
\text { (Season 4) }\end{array}$ & \\
\hline Amanda & $0.1854 \mathrm{aA}$ & $0.1581 \mathrm{bB}$ & $0.1452 \mathrm{aB}$ & $0.1504 \mathrm{aB}$ & 0.1598 \\
\hline Brasília & $0.1542 \mathrm{aA}$ & $0.1743 \mathrm{aA}$ & $0.1538 \mathrm{aA}$ & $0.1256 \mathrm{aB}$ & 0.1520 \\
\hline BRS Planalto & $0.1329 \mathrm{aB}$ & $0.1498 \mathrm{bA}$ & $0.1563 \mathrm{aA}$ & $0.1153 \mathrm{aB}$ & 0.1386 \\
\hline Érica & $0.1687 \mathrm{aA}$ & $0.1615 \mathrm{bA}$ & $0.1367 \mathrm{bA}$ & $0.1367 \mathrm{aA}$ & 0.1542 \\
\hline Francine & $0.1653 \mathrm{aA}$ & $0.1572 \mathrm{bA}$ & $0.1273 \mathrm{bB}$ & $0.1136 \mathrm{aB}$ & 0.1409 \\
\hline Kuronan & $0.1662 \mathrm{aA}$ & $0.1965 \mathrm{aA}$ & $0.1418 \mathrm{aB}$ & $0.1359 \mathrm{aB}$ & 0.1601 \\
\hline Mariana & $0.1559 \mathrm{aB}$ & $0.1854 \mathrm{aA}$ & $0.1469 \mathrm{aB}$ & $0.1111 \mathrm{aC}$ & 0.1498 \\
\hline Melinda & $0.1854 \mathrm{aA}$ & $0.1623 \mathrm{bA}$ & $0.1273 b B$ & $0.1444 \mathrm{aB}$ & 0.1549 \\
\hline Nativa & $0.1551 \mathrm{aA}$ & $0.1273 \mathrm{bA}$ & $0.1102 \mathrm{bB}$ & $0.1239 \mathrm{aB}$ & 0.1291 \\
\hline Suprema & $0.1653 \mathrm{aA}$ & $0.1606 \mathrm{bA}$ & $0.1649 \mathrm{aA}$ & $0.1282 \mathrm{aB}$ & 0.1547 \\
\hline Means & 0.1634 & 0.1633 & 0.1411 & 0.1278 & \\
\hline
\end{tabular}

Means followed by the same letter do not differ statistically (uppercase in the row and lowercase in the column) using the Scott-Knott test at $5 \%$ probability.

Table 7: Soluble solids/titratable acidity ratio $\left({ }^{\circ} \mathrm{Brix} / \%\right)$ in carrot roots as a function of the planting date. Mossoró, RN. Ufersa, 2017

\begin{tabular}{|c|c|c|c|c|c|}
\hline \multirow{3}{*}{ Cultivars } & \multicolumn{5}{|c|}{ SS/TA ratio $\left({ }^{\circ}\right.$ Brix $\left./ \%\right)$} \\
\hline & \multicolumn{4}{|c|}{ Planting dates } & \multirow[b]{2}{*}{ Mean } \\
\hline & $\begin{array}{c}\text { May } \\
\text { (Season 1) }\end{array}$ & $\begin{array}{c}\text { June } \\
\text { (Season 2) }\end{array}$ & $\begin{array}{c}\text { July } \\
\text { (Season 3) }\end{array}$ & $\begin{array}{c}\text { August } \\
\text { (Season 4) }\end{array}$ & \\
\hline Amanda & $56.29 \mathrm{aB}$ & $63.23 \mathrm{aB}$ & $77.51 \mathrm{bA}$ & $69.76 \mathrm{bA}$ & 66.70 \\
\hline Brasília & $61.98 \mathrm{aB}$ & $55.19 \mathrm{aB}$ & $72.51 \mathrm{bA}$ & $79.52 \mathrm{bA}$ & 67.30 \\
\hline BRS Planalto & $70.10 \mathrm{aA}$ & $60.25 \mathrm{aB}$ & $74.08 \mathrm{bA}$ & $81.83 \mathrm{bA}$ & 71.57 \\
\hline Érica & $60.95 \mathrm{aA}$ & $63.26 \mathrm{aA}$ & $81.10 \mathrm{bA}$ & $62.91 \mathrm{bA}$ & 68.01 \\
\hline Francine & $62.77 \mathrm{aB}$ & $66.25 \mathrm{aB}$ & $87.27 \mathrm{aA}$ & $93.75 \mathrm{aA}$ & 77.51 \\
\hline Kuronan & $58.85 \mathrm{aB}$ & $46.99 \mathrm{aB}$ & $72.67 \mathrm{bA}$ & $71.93 \mathrm{bA}$ & 62.61 \\
\hline Mariana & $65.18 \mathrm{aC}$ & $55.84 \mathrm{aC}$ & $77.90 \mathrm{bB}$ & $98.97 \mathrm{aA}$ & 74.48 \\
\hline Melinda & $55.00 \mathrm{aC}$ & $67.18 \mathrm{aC}$ & $88.27 \mathrm{aA}$ & $72.68 b B$ & 70.78 \\
\hline Nativa & $62.16 \mathrm{aC}$ & $71.51 \mathrm{aC}$ & $101.32 \mathrm{aA}$ & $82.21 \mathrm{bB}$ & 79.30 \\
\hline Suprema & $61.81 \mathrm{aA}$ & $58.91 \mathrm{aA}$ & $68.22 \mathrm{bA}$ & $77.01 \mathrm{bA}$ & 66.49 \\
\hline
\end{tabular}

Means followed by the same letter do not differ statistically (uppercase in the row and lowercase in the column) using the Scott-Knott test at $5 \%$ probability.

Rev. Ceres, Viçosa, v. 67, n.5, p. 357-364, sep/oct, 2020 
Table 8: Total soluble sugars (\%) in carrot roots as a function of the planting date. Mossoró, RN. Ufersa, 2017

\begin{tabular}{lccccc}
\hline & \multicolumn{5}{c}{ Total Soluble Sugars (\%) } \\
\cline { 2 - 4 } Cultivars & \multicolumn{5}{c}{ Planting dates } \\
\cline { 2 - 4 } & $\begin{array}{c}\text { May } \\
\text { (Season 1) }\end{array}$ & $\begin{array}{c}\text { June } \\
\text { (Season 2) }\end{array}$ & $\begin{array}{c}\text { July } \\
\text { (Season 3) }\end{array}$ & $\begin{array}{c}\text { August } \\
\text { (Season 4) }\end{array}$ & Mean \\
\hline Amanda & $9.33 \mathrm{aA}$ & $8.89 \mathrm{aA}$ & $7.15 \mathrm{bB}$ & $7.25 \mathrm{aB}$ & 8.16 \\
Brasília & $7.55 \mathrm{bA}$ & $5.37 \mathrm{bB}$ & $7.86 \mathrm{aA}$ & $6.81 \mathrm{aA}$ & 6.91 \\
BRS Planalto & $7.09 \mathrm{bA}$ & $5.51 \mathrm{bB}$ & $7.84 \mathrm{aA}$ & $6.35 \mathrm{aB}$ & 6.70 \\
Érica & $9.46 \mathrm{aA}$ & $9.46 \mathrm{aA}$ & $6.24 \mathrm{bB}$ & $5.99 \mathrm{aB}$ & 8.21 \\
Francine & $9.47 \mathrm{aA}$ & $9.00 \mathrm{aA}$ & $7.12 \mathrm{bA}$ & $6.38 \mathrm{aB}$ & 7.99 \\
Kuronan & $7.13 \mathrm{bA}$ & $6.50 \mathrm{bA}$ & $7.08 \mathrm{bA}$ & $7.23 \mathrm{aA}$ & 6.99 \\
Mariana & $8.88 \mathrm{aA}$ & $8.27 \mathrm{aA}$ & $6.72 \mathrm{bB}$ & $6.87 \mathrm{aB}$ & 7.69 \\
Melinda & $7.28 \mathrm{bB}$ & $10.08 \mathrm{aA}$ & $8.53 \mathrm{aB}$ & $7.22 \mathrm{aB}$ & 8.28 \\
Nativa & $7.89 \mathrm{bA}$ & $6.00 \mathrm{bB}$ & $8.25 \mathrm{aA}$ & $7.15 \mathrm{aA}$ & 7.33 \\
Suprema & $7.95 \mathrm{bA}$ & $5.35 \mathrm{bB}$ & $6.86 \mathrm{bA}$ & $5.68 \mathrm{aB}$ & 6.46 \\
\hline Mean & 8.21 & 7.45 & 7.37 & 6.76 & \\
\hline
\end{tabular}

Means followed by the same letter do not differ statistically (uppercase in the row and lowercase in the column) using the Scott-Knott test at $5 \%$ probability.

Table 9: Beta-carotene content $\left(\mathrm{mg} .100 \mathrm{~g}^{-1}\right)$ in the carrot cultivars and different planting dates. Mossoró, RN. Ufersa, 2017

\begin{tabular}{lc}
\hline Cultivars & Beta-carotene $\left(\mathbf{m g . 1 0 0 g}^{-1}\right)$ \\
\hline Amanda & $2.78 \mathrm{a}$ \\
Brasília & $1.68 \mathrm{~b}$ \\
BRS Planalto & $2.50 \mathrm{a}$ \\
Érica & $2.47 \mathrm{a}$ \\
Francine & $2.36 \mathrm{a}$ \\
Kuronan & $2.06 \mathrm{~b}$ \\
Mariana & $2.59 \mathrm{a}$ \\
Melinda & $2.78 \mathrm{a}$ \\
Nativa & $2.73 \mathrm{a}$ \\
Suprema & $2.30 \mathrm{a}$ \\
\hline
\end{tabular}

\begin{tabular}{lc}
\hline Planting date & Beta-carotene $\left(\mathbf{m g . 1 0 0 g}^{-1}\right)$ \\
\hline May (Season 1) & $2.50 \mathrm{~b}$ \\
June (Season 2) & $2.41 \mathrm{~b}$ \\
July (Season 3) & $2.80 \mathrm{a}$ \\
August (Season 4) & $1.96 \mathrm{c}$ \\
\hline
\end{tabular}

* Averages followed by the same letter do not differ statistically from each other by the Scott-Knott test at 5\% probability.

to each other. The Brasília cultivar, which has been the most recommended cultivar for summer cultivation, once again exhibited the worst performance among the ten cultivars studied.

Regarding the planting dates, carrots planted in July showed, on average, the highest content of beta-carotene in the roots, while carrots planted in August (Season 4) had the lowest content.

One of the main climatic factors that influences the content of carotenoids in carrots is air temperature. Air temperatures ranging from 16 to $25^{\circ} \mathrm{C}$ are considered ideal for the synthesis of beta-carotene (Vieira \& Pessoa, 1997). The average temperatures in the study area, during the entire period of the experiment, were above the ideal range for the synthesis of beta-carotene, which would justify the low levels of this pigment found here.

\section{CONCLUSIONS}

The interaction between the carrot cultivars and the planting dates had a significant influence on postharvest quality of carrot roots.

For the study area, the cultivation of carrots in May and June is most recommended, since the July and August plantings resulted in a decrease in marketability, mainly due to a higher occurrence of white halo in the roots.

Finally, further studies should be conducted to find ways to attenuate the occurrence of white halo and cultivate carrots throughout the year in regions with hot climates.

\section{ACKNOWLEDGMENTS, FINANCIAL SUPPORT AND FULL DISCLOSURE}

The authors declare no financial or other competing conflicts of interest.

\section{REFERENCES}

Alves SSV, Negreiros MZ, Aroucha EMM, Lopes WAR, Teófilo TMS, Freitas FCL \& Nunes GHS (2010) Qualidade de cenouras em diferentes densidades populacionais. Revista Ceres, 57:218-223.

Allen RG, Pereira LS, Raes D \& Smith M (2006) Evapotranspiración del cultivo: Guías para la determinación de los requerimentos de agua de los cultivos. Roma, FAO. 298p. (Cuadernos técnicos: Riego y Drenaje, 56).

Bezerra Neto F, Oliveira LJ, Santos AP, Lima JSS \& Silva IN (2014) Otimização agroeconômica da cenoura fertilizada com diferentes doses de jitirana. Revista Ciência Agronômica, 2:305-311.

Carmo Filho F, Espínola Sobrinho J \& Maia Neto JM (1991) Dados meteorológicos de Mossoró (jan. de 1988 a dez. de 1990). Mossoró, ESAM/FGD. 110p. (Coleção Mossoroense, 630). 
Embrapa - Empresa Brasileira de Pesquisa Agropecuária (2013) Sistema brasileiro de classificação de solos. $3^{a}$ ed. Brasília, Embrapa. 412p.

Ferreira DF (2003) SISVAR: programa estatístico, versão 5.3 (Build 75). Available at: http://www.dex.ufla.br/ danielff/programas/ sisvar.html. Accessed on: September 12 $2^{\text {th }}, 2018$.

Figueiredo Neto A, Oliveira SB, Lima MS, Amorim MR \& Figueiredo RMC (2010) Efeito do composto orgânico nas características físico-químicas de cenoura "Brasília". Revista Brasileira de Produtos Agroindustriais, 12:61-66.

Grangeiro LC, Azevêdo PE, Nunes GHS, Dantas MSM \& Cruz CA (2012) Desempenho e divergência genética de cenoura 'Brasília' em função da procedência das sementes. Horticultura Brasileira, 30:137-142

Hoppu U, Puputti S \& Sandell M (2020) Factors related to sensory properties and consumer acceptance of vegetables. Critical Reviews in Food Science and Nutrition, 3:02-11.

Instituto Adolfo Lutz (2008) Metodos físico-químicos para análise de alimentos. $4^{\mathrm{a}}$ ed. Brasília, Anvisa. 1020p.

Mattiuz BH (2007) Fatores da pré-colheita influenciam a qualidade final dos produtos. Visão Agrícola, 7:18-21.

Nagata M \& Yamashita I (1992) Simple method for simultaneous determination of chlorophyll and carotenoids in tomato fruit. Nippon Shokuhin Kogyo Gakkaishi, 39:925-928.

Paulus D, Moura CA, Santin A, Dalhem AR, Nava GA \& Ramos CEP (2012) Produção e aceitabilidade de cenoura sob cultivo orgânico no inverno e no verão. Horticultura Brasileira, 30:446452 .

Pereira RB, Carvalho ADF, Pinheiro JB, Silva GO \& Vieira JV (2015) Avaliação de híbridos experimentais de cenoura no Distrito Federal. Horticultura Brasileira, 1:34-39.

Pereira VS (2014) Caracterização físico-química, carotenoides totais e elementos-traço em cenoura (Daucus carota L.) e tomate (Lycopersicon esculentum) orgânico e convencional. Dissertação de Mestrado. Universidade Federal de Minas Gerais, Belo Horizonte. 117p.
Pimentel-Gomes F (2009) Curso de estatística experimental. 15 ed. Piracicaba, ESALQ. 451p.

Reid JB \& Gillespie RN (2017) Yield and quality responses of carrots (Daucus carota L.) to water deficits. New Zealand Journal of Crop and Horticultural Science, 45:299-312.

Resende GM, Yuri JE, Costa ND \& Mota JH (2016) Desempenho de cultivares de cenoura em sistema orgânico de cultivo em condições de temperaturas elevadas. Horticultura Brasileira, 34:121-125.

Seljåsen R, Kristensen HL, Lauridsen C, Wyss GS, Kretzschmar U, Birlouez-Aragone I, and Kahl J (2013) Quality of carrots as affected by pre- and postharvest factors and processing. Journal of the Science of Food and Agriculture 11:2611-2626.

Schifferstein HNJ, Wehrle T \& Carbon CC (2018) Consumer expectations for vegetables with typical and atypical colors: the case of carrots. Food Quality and Preference, 72:98-108.

Silva GO, Vieira JV \& Nascimento WM (2011) Estratégias de seleção para germinação de sementes de cenoura em altas temperaturas. Semina: Ciências Agrárias, 32:849-854.

Soltoft M, Nielsen J, Lauren KH, Husted S, Halekoh U \& Knuthsen P (2010) Effects of organic and conventional growth systems on the content of flavonoids in onions and phenolic acids in carrots and potatoes. Journal of Agricultural and Food Chemistry, 58:10323-10329.

Southgate DAT (1991) Determination of food carbohydrates. London, Elsevier Applied Science. 178p.

Taiz L \& Zeiger RE (2017) Fisiologia vegetal. 6 a ed. Porto Alegre, Artmed. 888p.

Umuhoza JNK, Sylvestre H \& Philippe S (2014) Nutritional quality of carrot (Daucus carota L.) as influenced by farm yard manure. World Science Research Journals, 2:102-107.

Vieira JV \& Pessoa HBSV (1997) Cultivares. Cultivo da cenoura (Daucus carota L.). Brasília, Embrapa Hortaliças. 19p. 